\title{
Environmentally Benign Neem Biodiesel Synthesis Using Nano-Zn-Mg-Al Hydrotalcite as Solid Base Catalysts
}

\author{
Karthikeyan Chelladurai and Manivannan Rajamanickam \\ Department of Chemistry, Government Arts College (Autonomous), Kumbakonam, Tamilnadu 612001, India \\ Correspondence should be addressed to Manivannan Rajamanickam; rmanivan@hotmail.com
}

Received 5 December 2013; Revised 30 June 2014; Accepted 20 July 2014; Published 21 August 2014

Academic Editor: Vivek Srivastava

Copyright ( 2014 K. Chelladurai and M. Rajamanickam. This is an open access article distributed under the Creative Commons Attribution License, which permits unrestricted use, distribution, and reproduction in any medium, provided the original work is properly cited.

\begin{abstract}
Hydrotalcite, also known as aluminum-magnesium layered double hydroxide (LDH) or anionic clay, is a synthetic compound that was broadly investigated in the past decade due to its many potential applications. In this work, we present an environmentally benign process for the transesterification (methanolysis) of neem oil to fatty acid methyl esters (FAME) using Zn-Mg-Al hydrotalcites as solid base catalysts in a heterogeneous manner. The catalysts were characterized by XRD, FT-IR, TPD-CO 2 , and the BET surface area analysis. It is well-known that the catalytic performance of hydrotalcite is dramatically increased through the incorporation of $\mathrm{Zn}$ into the surface of $\mathrm{Mg}$-Al hydrotalcite material. The optimized parameters, $10: 1 \mathrm{methanol} / \mathrm{oil} \mathrm{molar} \mathrm{ratio} \mathrm{with}$ $7.5 \mathrm{~g}$ catalysts reacted under stirring speed $450 \mathrm{rpm}$ at $65^{\circ} \mathrm{C}$ for $4 \mathrm{~h}$ reaction, gave a maximum ester conversion of $90.5 \%$ for the sample with $\mathrm{Zn}-\mathrm{Mg}-\mathrm{Al}$ ratio of $3: 3: 1$.
\end{abstract}

\section{Introduction}

Biodiesel is a promising nontoxic and biodegradable renewable fuel comprised of monoalkyl esters of long chain fatty acids, which are derived from vegetable oils or animal fats [1]. It has attracted attention during the past few years as a renewable and environmental friendly fuel. The transesterification reaction consists of transforming triglycerides into fatty acid alkyl esters, in the presence of an alcohol, such as methanol or ethanol, and a catalyst, such as an alkali or acid, with glycerol as a byproduct [2]. Nearly $60-80 \%$ of the total biodiesel production cost is attributed to biodiesel feedstock. Using cheaper feedstock, such as nonedible oil, animal fats, untreated crude edible oil, or waste cooking oil, has been suggested to lower the feedstock cost [3-5]. Neem oil was selected as a nonedible feedstock for biodiesel production.

Mixed metal oxides (hydrotalcites) are ones of the base catalysts affording good catalytic activity for the methanolysis of vegetable oil. Because the actual active sites of the hydrotalcites participating in catalysis situated at the edges of crystals, the smaller crystals have a larger number of active sites [6]. The hydrotalcite is a kind of double-layered hydroxides (LDHs) composed of the brucite-like layers, and $\mathrm{Mg}^{2+}$ and
$\mathrm{Al}^{3+}$ cations coordinate an octahedral structure. When $\mathrm{Al}^{3+}$ replaces $\mathrm{Mg}^{2+}$, a positive charge is generated in the layer, which is balanced by $\mathrm{CO}_{3}{ }^{2-}$ or $\mathrm{OH}^{-}$located between the brucite-like cation layers $[7,8]$. The interesting property of the oxides obtained by calcination of $\mathrm{LDHs}$ around $400^{\circ} \mathrm{C}$ is the formation of highly active homogenous mixed oxides which are potentially used as basic catalysts and catalyst supports $[9,10]$. We have already reported $\mathrm{Mg}$-Al catalysts with neem oil that gave a maximum ester conversion of $84 \%$ for the sample with 3:1 molar ratio [11]. In this present work, an environmentally benign process for the methanolysis of neem oil to fatty acid methyl esters using $\mathrm{Zn}-\mathrm{Mg}$-Al nanohydrotalcite as solid base catalysts in a heterogeneous manner was analyzed.

\section{Materials and Methods}

Neem oil was purchased from local market, chemicals such as $\mathrm{Zn}\left(\mathrm{NO}_{3}\right)_{2} \cdot 6 \mathrm{H}_{2} \mathrm{O}, \mathrm{Mg}\left(\mathrm{NO}_{3}\right)_{2} \cdot 6 \mathrm{H}_{2} \mathrm{O}$, and $\mathrm{Al}\left(\mathrm{NO}_{3}\right)_{3} \cdot 9 \mathrm{H}_{2} \mathrm{O}$ were purchased from Merck, and methanol, $\mathrm{NaOH}$, and $\mathrm{Na}_{2} \mathrm{CO}_{3}$ were purchased from Sigma Aldrich. All chemicals used were of analytical reagent grade. 
TABLE 1: Chemical composition analysis and physicochemical properties of $\mathrm{Zn}-\mathrm{Mg}$-Al hydrotalcites.

\begin{tabular}{|c|c|c|c|c|c|c|}
\hline \multirow{2}{*}{ Catalysts } & \multirow{2}{*}{ Theoretical ratio $\mathrm{Zn} / \mathrm{Mg} / \mathrm{Al}$} & \multirow{2}{*}{ Experimental ratio ${ }^{a} \mathrm{Zn} / \mathrm{Mg} / \mathrm{Al}$} & \multicolumn{3}{|c|}{ Unit cell parameters $(\AA)$} & \multirow{2}{*}{ BET surface area $\left(\mathrm{m}^{2} / \mathrm{g}\right)^{\mathrm{b}}$} \\
\hline & & & $a$ & $c$ & $c^{\prime}$ & \\
\hline $\begin{array}{l}\text { HT-1 } \\
\end{array}$ & $2: 2: 1$ & $1.96 / 1.89 / 1$ & 3.042 & 22.73 & 7.31 & 166.4 \\
\hline HT-2 & $2: 3: 1$ & $1.93 / 1.98 / 1$ & 3.058 & 22.89 & 7.57 & 188.6 \\
\hline HT-3 & $3: 3: 1$ & $3.02 / 2.98 / 1$ & 3.063 & 22.95 & 7.72 & 220.8 \\
\hline HT-4 & $3: 4: 1$ & $2.85 / 4.08 / 1$ & 3.088 & 23.59 & 7.94 & 208.4 \\
\hline
\end{tabular}

${ }^{a}$ Experimental $\mathrm{Mg}-\mathrm{Zn}-\mathrm{Al}$ atomic ratios in the synthesized catalyst determined by EPMA.

${ }^{\mathrm{b}} \mathrm{BET}$ surface area calcined at $500^{\circ} \mathrm{C} / 8 \mathrm{~h}$.

2.1. Catalysts Preparation. Zn-Mg-Al hydrotalcite was prepared from nitrate salts. Solution A contains various molar ratios of $\mathrm{Zn}\left(\mathrm{NO}_{3}\right)_{2} \cdot 6 \mathrm{H}_{2} \mathrm{O}, \mathrm{Mg}\left(\mathrm{NO}_{3}\right)_{2} \cdot 6 \mathrm{H}_{2} \mathrm{O}$, and $\mathrm{Al}\left(\mathrm{NO}_{3}\right)_{3} \cdot 9 \mathrm{H}_{2} \mathrm{O}$ and solution $\mathrm{B}$ contains $2 \mathrm{M} \mathrm{NaOH}$ and $0.125 \mathrm{M} \mathrm{Na}_{2} \mathrm{CO}_{3}$. Solution $\mathrm{B}$ is added to solution $\mathrm{A}$ under vigorous stirring at $65^{\circ} \mathrm{C}$ for $48 \mathrm{~h}$, maintaining the $\mathrm{pH}$ between 8 and 10. The resulting white precipitate was filtered and washed to eliminate the alkali metal ions and the nitrate ions and catalysts were dried at $110^{\circ} \mathrm{C}$ overnight. The samples were then calcined at $500^{\circ} \mathrm{C}$ in a muffle furnace for $8 \mathrm{~h}$, with a heating rate of $8 \mathrm{~K} \cdot \mathrm{min}^{-1}$. For convenience, the hydrotalcites thus obtained with different $\mathrm{Zn}-\mathrm{Mg}$-Al molar ratios of $2: 2: 1$, $2: 3: 1,3: 3: 1$, and $3: 5: 1$ were designated as HT-1, HT-2, HT3 , and HT-4.

2.2. Catalysts Characterization. The crystalline characteristic was determined by using the X-ray diffraction instrument Siemens D-diffractometer using $\mathrm{CuK} \alpha$ radiation $(\lambda=$ $\left.1.5406^{\circ} \mathrm{A}\right)$. Scans were performed over the $2 \theta$ range from $5^{\circ}$ to $75^{\circ}$. The particle size of the hydrotalcite was calculated using the Scherer equation. A FEI QUANTA200 Fourier transform infrared (FT-IR) spectrum was recorded on a Nicolet 5DX spectrophotometer using $\mathrm{KBr}$ pellet technique. Gas chromatography analysis was performed on a GC2010 (Shimadzu, Japan). The chemical composition of the synthesized samples was determined using a JEOL JCXA 733 EPMA (electron probe microanalysis). The specific surface area was measured by the flow method using Micromeritics Pulse Chemisorb 2700 instrument.

2.3. Catalytic Activity. The catalytic activity was evaluated using the transesterification of crude neem oil with methanol. Transesterification experiments were carried out in a fournecked flask. A specified amount of $\mathrm{Zn}-\mathrm{Mg}$-Al mixed metal oxide catalyst and the required volume of methanol were added to the reaction mixture of $20.0 \mathrm{~g}$ of neem oil. The reactant mixture was then heated to $120^{\circ} \mathrm{C}$ under maximum agitation ( $450 \mathrm{rpm}$ of stirring). At the end of the experiment, the catalyst was separated from the product using a centrifuge, and the reaction mixture was then loaded into a rotary evaporator to remove excess methanol. The top layer was the biodiesel phase of the methyl esters and lower phase was glycerin. The chemical analysis was carried out by the gas chromatography.

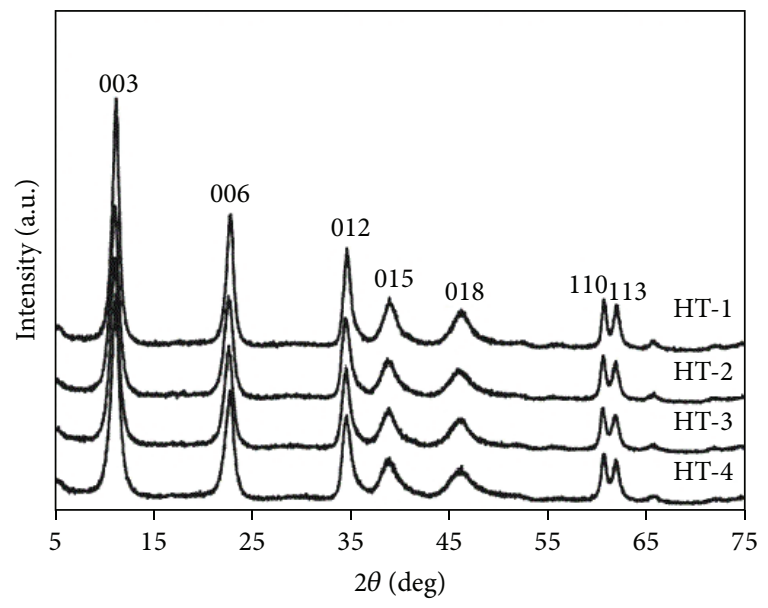

FIGURE 1: XRD patterns of HT-1, HT-2, HT-3, and HT-4.

\section{Result and Discussion}

3.1. X-Ray Diffraction Analysis. The XRD pattern of $\mathrm{Zn}$ $\mathrm{Mg} / \mathrm{Al}$ catalyst (Figure 1) is corresponding to a typical hydrotalcite structure with strong, sharp, and symmetric peaks for the (003), (006), (110), and (113) planes as well as broad and symmetric peaks for the (015) and (018) planes, which could be attributed to the overlapping $\mathrm{MgO}$ and/or $\mathrm{ZnO}$ diffraction lines $[12,13]$. The three strong peaks at $2 \theta$ values of about $11.46^{\circ}, 23.28^{\circ}$, and $33.57^{\circ}$ are characteristic of a layered structure. The difference in the intensities of the reflections from one sample to another indicates different degrees of crystallinity when the cationic composition varies. The peaks of $\mathrm{Al}_{2} \mathrm{O}_{3}$ phase were very small, indicating that $\mathrm{Al}^{3+}$ cations were dispersed in the structure of $\mathrm{MgO}$ without the formation of spinel species [14].

The cationic ratio in the synthesized hydrotalcites was in good agreement with the theoretical one, as the EPMA results showed no major changing in the final composition. The unit cell parameters were done by the peaks indexing in the hexagonal crystal system which was presented in Table 1 . The values obtained here are close to previously reported data for similar materials $[15,16]$. It can be noticed that the value " $a$ " is not influenced by the nature of divalent cations incorporated in the brucite-like layers and do not lead to distortions in the octahedral planes. [17] The $a$ and $c$ parameters decreased with increasing aluminum content, which can be explained 


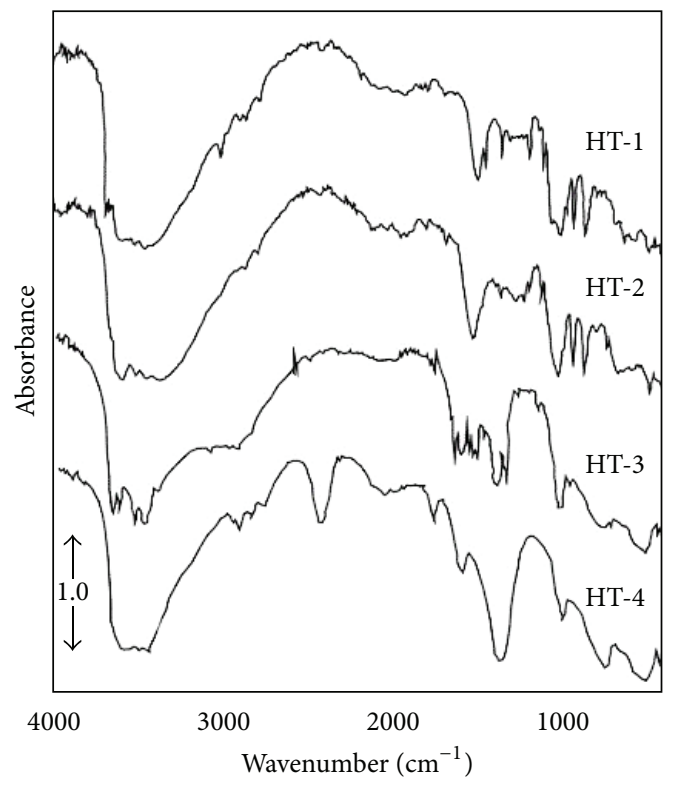

Figure 2: FT-IR spectra of HT-1, HT-2, HT-3, and HT-4.

by the substitution of larger $\mathrm{Mg}^{2+}$ ions by smaller $\mathrm{Al}^{3+}$ ions [15]. It also indicates that the incorporation of $\mathrm{Zn}$ leads to an increase in stress in the octahedral hydroxide layer in the hydrotalcite crystal structure, due to the difference in ionic radii between $\mathrm{Mg}^{2+}$ and $\mathrm{Zn}^{2+}$ as there are no differences in the bond lengths around a single octahedral site. The average particle size was calculated as $20 \mathrm{~nm}$ by the Scherer equation $[\mathrm{Dc}=k(\lambda / \beta) \cdot(\cos \theta)]$ where $\mathrm{Dc}$ is the average particle size, $k$ is the Scherer constant (0.89), $\lambda$ is the X-ray wavelength, $(\mathrm{CuK} \alpha)=0.1541 \mathrm{~nm}, \beta$ is the FWHM (full-width at halfmaximum), and $\theta$ is the diffraction angle in the XRD (003) reflection [18].

3.2. FT-IR Analysis. FT-IR spectroscopy showed characteristic frequencies associated with the presence of intercalated anions. In all samples, a broad band between 3600 and $3400 \mathrm{~cm}^{-1}$ was observed (Figure 2) and represents the stretching vibrations of the $\mathrm{O}-\mathrm{H}$ groups of the inorganic and interlayer water. If the various metals in the hydrotalcites $(\mathrm{Mg}, \mathrm{Zn}, \mathrm{Al})$ are distributed at random, in most cases one hydroxyl group will be coordinated by at least two different metal cations [9]. Another common frequency for LDHlike materials is the presence of the bending vibrations of water molecules at $1600 \mathrm{~cm}^{-1}$ [10]. Two bands very close together assigned to the $v 3$ have been observed around 1360 and $1370 \mathrm{~cm}^{-1}$ in HT-3, while in the literature one band is described around $1400 \mathrm{~cm}^{-1}$ [19]. This may indicate that two different types of $\mathrm{CO}_{3}{ }^{2-}$ are present in the interlayer of the hydrotalcite, possibly associated with the location near octahedral either containing $\mathrm{Mg}$ or $\mathrm{Zn}$. In the case of HT-4, the absorption centered at $1380 \mathrm{~cm}^{-1}$ is assigned to the presence of nitrate anions within the structure. The bond located around $780 \mathrm{~cm}^{-1}$ identified in the FTIR spectra may be due to the $\mathrm{Al}-\mathrm{O}, \mathrm{Zn}-\mathrm{Al}-\mathrm{O}$, or $\mathrm{Mg}-\mathrm{Al}-\mathrm{O}$ bond vibration in the brucite-like layer [20]. The relatively broad bands at 950 and $1030 \mathrm{~cm}^{-1}$ have not been reported before for hydrotalcite. These bands, which were also observed in the $\mathrm{Zn} / \mathrm{Al}$-hydrotalcite, are absent in the spectrum of brucite, $\mathrm{Mg}(\mathrm{OH})_{2}$, the structure from which hydrotalcite can be derived [10]. Therefore, the FTIR characterization of the hydrotalcite structure reflects the coexistence of a strong band with a weak band. In all the samples the main characteristic peaks are quite similar and comparable to previously published data $[21,22]$.

3.3. TPD- $\mathrm{CO}_{2}$ Analysis. The TPD- $\mathrm{CO}_{2}$ measurements were carried out for the series of $\mathrm{Zn}-\mathrm{Mg}-\mathrm{Al}$ catalysts to determine the total basicity and basic strength distribution of the catalyst. The $\mathrm{CO}_{2}$ desorption shows that the main peaks were found at $T_{\max }$ ranging from 100 to $150^{\circ} \mathrm{C}$ is attributed to the interaction of $\mathrm{CO}_{2}$ with the weak basic sites present in the catalyst, while the others found at varying from 200 to $500^{\circ} \mathrm{C}$ are due to the interaction of $\mathrm{CO}_{2}$ with the medium basic sites of the catalysts system, which were generated from the $\mathrm{Mg}^{2+}-\mathrm{O}^{2-}$ ion pairs. The $\mathrm{Al}^{3+}$ cations in $\mathrm{MgO}$ lattice created a defect in order to compensate the positive charge generated and the adjacent oxygen anions became coordinatively unsaturated. The final basicity of these catalysts and the electronic state of the metallic phase depend on parameters such as $\mathrm{M}(\mathrm{II}) / \mathrm{M}$ (III) ratio, the nature of compensating anions, and thermal treatment [23]. The basicity of HT-1, HT-2, HT-3, and HT-4 is $82,93.5,220.8$, and 228.7 , respectively. The basicity of a catalyst was raised from HT- 1 to HT- 4 because the synergetic effect between $\mathrm{Mg}$ and $\mathrm{Zn}$ increased the catalyst basicity.

3.4. BET Surface Area Measurement. The BET surface area of calcined samples having different composition is given in Table 1. Thermal decomposition of hydrotalcite precursors led to the formation of high surface area. Also creation of large surface area is an important characteristic needed for catalysis. Surface areas of calcined hydrotalcite were significantly higher than in uncalcined hydrotalcite samples [24]. The increase in surface area during calcination at $500^{\circ} \mathrm{C}$ can be attributed to the formation of mesopores due to expulsion of $\mathrm{CO}_{2}$ and $\mathrm{H}_{2} \mathrm{O}$ from the hydrotalcite precursors [25]. The higher surface area in case of 3:3:1 in $\mathrm{Zn}-\mathrm{Mg}-\mathrm{Al}$ ratio compared to other catalyst composition may be due to the presence of equal amount of $\mathrm{Zn}$ metal-support interaction in the $\mathrm{Mg}-\mathrm{O}$ lattice that modifies the atomic and electronic structure of catalyst [26].

3.5. Methanolysis of Neem Oil. This transesterification reaction could be mainly influenced by the following factors: amount of catalysts, reaction time, methanol/oil molar ratio, reaction temperature, and molar ratio of $\mathrm{Zn}-\mathrm{Mg}-\mathrm{Al}$. The effect of catalyst amount on FAME yield was studied; when increasing the amount of catalyst, the slurry (mixture of catalyst and reactants) becomes too viscous giving rise to a problem of mixing and a demand of higher power consumption for adequate stirring. On the other hand, when the catalyst amount is not sufficient, maximum conversion 
TABLE 2: Effect of $\mathrm{Zn} / \mathrm{Mg} / \mathrm{Al}$ molar ratio on product distribution and conversion.

\begin{tabular}{lcccc}
\hline Catalysts & \multirow{2}{*}{$\mathrm{Zn} / \mathrm{Mg} /$ Al molar ratio } & Conversion Wt (\%) & \multicolumn{2}{c}{ Product selectivity Wt (\%) } \\
HT-1 & $2: 2: 1$ & 32 & 43.49 & 23.51 \\
HT-2 & $2: 3: 1$ & 43 & 65.12 & 19.88 \\
HT-3 & $3: 3: 1$ & 56 & 92.5 & 10.02 \\
HT-4 & $3: 5: 1$ & 49 & 88.3 & 6.35 \\
\hline
\end{tabular}

Note: FAME: fatty acid methyl ester.

Temperature: $65^{\circ} \mathrm{C}$.

Neem oil: methanol: $10: 1$

Catalyst weight: $7.5 \mathrm{~g}$.

cannot be reached. The maximum yield is obtained when the catalyst amount is $7.5 \mathrm{~g}$, due to increasing the contact between catalyst and reactants. The rate of methanolysis reaction is strongly influenced by the reaction time. The conversion increased progressively with increasing reaction time and then reached a plateau value representative of a nearly equilibrium conversion. The maximum conversion of $90.5 \%$ is obtained at $4 \mathrm{~h}$ reaction time; after $4 \mathrm{~h}$ reaction time yield was decreased probably due to reverse reaction (formation of triglycerides).

The conversion and the viscosity of produced ester depended on the molar ratio of methanol to vegetable oil which was one of the most important variables. But when mass transfer is limited due to problems of mixing, the mass transfer rate seems to be much slower than the reaction rate, so the conversion can be elevated by introducing excess amount of the reactant methanol to shift the equilibrium to the right-hand side. Higher molar ratios result in greater ester conversions in a shorter time [27]. The maximum yield was reached when the molar ratio was 10:1; higher molar ratio of methanol results in higher rate of esters formation and could ensure complete reaction. Excessive methanol had no significant effect on the yield.

3.5.1. Effect of Reaction Temperature. The effect of reaction temperature on the ester conversion was studied with the catalyst at various temperatures in Figure 3 . The transesterification proceeded slowly at $45^{\circ} \mathrm{C}$; at lower temperatures it resulted in a drop of the ester conversion because only a small amount of molecules was able to get over the required energy barrier. The ester conversion increased up to $92.5 \%$ when reaction temperature close to $65^{\circ} \mathrm{C}$. Thus, the optimum temperature for the preparation of the ester was found to be $65^{\circ} \mathrm{C}$, which was near the boiling point of anhydrous methanol. The conversion fell to about $60 \%$ in the temperature range of $75^{\circ} \mathrm{C}$, probably because the molar ratio of methanol to oil decreased when methanol reactant volatilized into gas phase above $65^{\circ} \mathrm{C}$, the boiling point of pure methanol.

\subsubsection{Effect of Molar Ratio of $\mathrm{Zn} / \mathrm{Mg} / \mathrm{Al}$ and Catalytic Studies.} The effect of molar ratio of $\mathrm{Zn} / \mathrm{Mg} / \mathrm{Al}$ and the catalytic activity studied at $65^{\circ} \mathrm{C}$ were illustrated in Figure 4, which indicates that the catalytic activity was improved with the increase in $\mathrm{Zn}$ and $\mathrm{Mg}$ content in $\mathrm{Zn} / \mathrm{Mg} / \mathrm{Al}$ molar ratio at

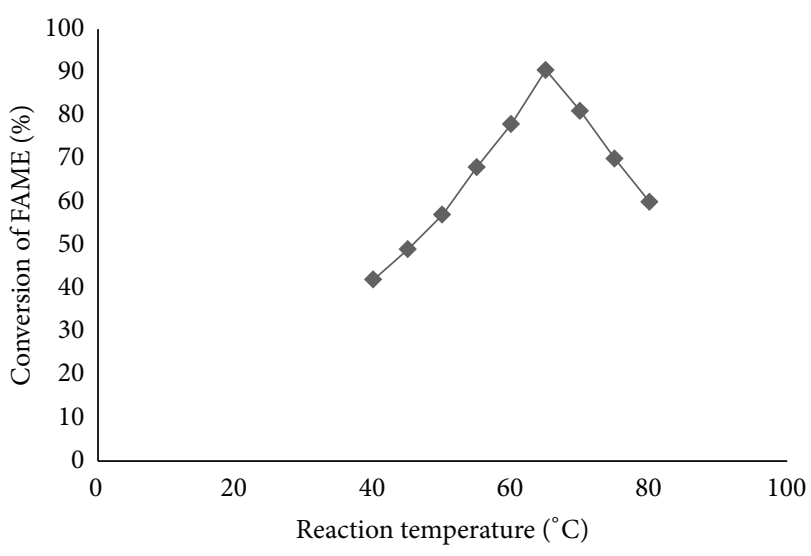

FIGURE 3: Effect of reaction temperature of HT-3 on conversion of FAME (\%).

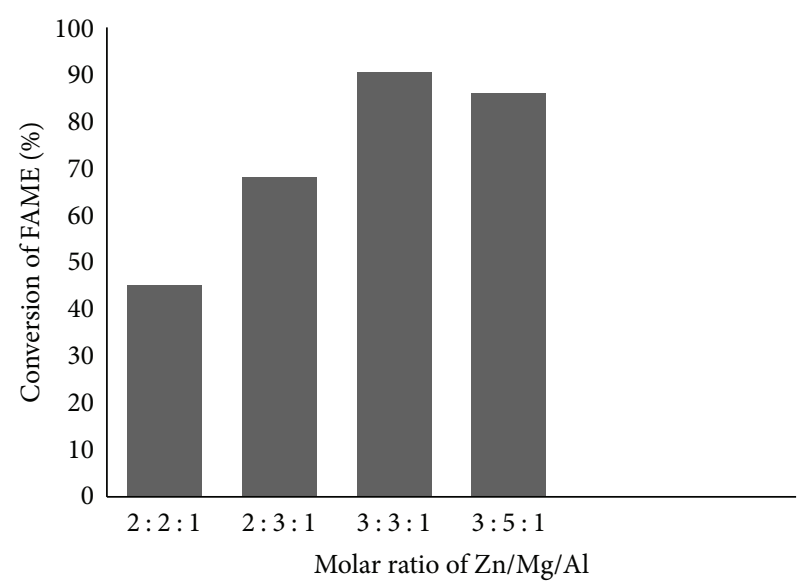

FIGURE 4: Effect of molar ratio of $\mathrm{Zn} / \mathrm{Mg} / \mathrm{Al}$ on conversion of FAME (\%) at $65^{\circ} \mathrm{C}$.

3:3:1; but increase in the $\mathrm{Mg}$ content in $\mathrm{Zn} / \mathrm{Mg} / \mathrm{Al}$ molar ratio at $3: 5: 1$, the catalytic activity dropped. The activity decreased in samples due to the formation of surface amorphous Al-O structure that partially covered $\mathrm{Mg}-\mathrm{O}$ pairs and decreased the concentration surface $\mathrm{O}^{2-}[15]$. The increased catalytic activity of the tertiary oxide system was due to the modification of the electronic properties between the oxides [26]. Table 2 showed various molar ratios of $\mathrm{Zn} / \mathrm{Mg} / \mathrm{Al}$ with 
product selectivity. The high activity of LDHS is due to the surface site of low $\left(\mathrm{OH}^{-}\right.$group), medium ( $\mathrm{Mg}-\mathrm{O}$ pairs), and strong ( $\mathrm{O}^{2-}$ anions) basicity [9]. The catalytic activity of the catalyst is also monitored through the percentage extent of formation of fatty acid methyl ester and glycerol conversion.

The higher catalytic activity HT-3 indicates the higher acidity of this catalyst which can be attributed to the dissolution of more amount of $\mathrm{Al}^{3+}$ in the $\mathrm{M}(\mathrm{II})-\mathrm{O}$ lattice introducing Lewis acidity. Also the $\mathrm{Zn}^{2+}$ ions in $\mathrm{Mg}^{2+}$ lattice, the acidic centers submerged in the basic matrix, may be resulting in concomitant acidic-basic centers and more in the presence of considerable amount of Lewis acidity in these compounds [10]. According to literature study, the main factor to influence transesterification activity is the alkalinity and the type of basic strength of the catalysts $[28,29]$. The linearity between FAME yield and total basicity was lightly deviated. HT-1 with lower number of basicity was found; this indicated that medium basic strength is less influencing in transesterification rate. In case of HT-3 and HT-4 with highest number of basicity, the FAME yield was higher than the latter. The author previously reported that the $\mathrm{M}$ (II)/ $\mathrm{Al}^{3+}$ hydrotalcites at ratio 3.0 showed higher acidity of this catalyst which can be attributed to the dissolution of more amount of $\mathrm{Al}^{3+}$ in the $\mathrm{M}(\mathrm{II})-\mathrm{O}$ lattice introducing Lewis acidity and also contain high density of Al-O pairs; lower and medium strength basic sites $\mathrm{Al}^{3+}-\mathrm{O}^{2-}$ pairs do not contribute much to the surface basicity. In contrast, both M(II) and M(III) cations provide Lewis acidic sites [9]. Biodiesel produced from the neem oil was analyzed by gas chromatography. The reaction studied with $\mathrm{HT}-3$ at $65^{\circ} \mathrm{C}$ and the results indicate neem biodiesel compositions like palmitic acid (C16:0) 13.79\%, palmitoleic acid (C16:1) 0.95\%, stearic acid (C18:0) 6.33\%, oleic acid (C18:1) 42.61\%, linoleic acid (C18:2) 26.34\%, and linolenic acid (C18:3) $0.06 \%$. The identified composition is compared with standard compounds. From the analysis data confirmed, the product is biodiesel phase of the methyl esters.

\section{Conclusions}

The present work has dealt with the transesterification of neem oil was studied in a heterogeneous system using calcined $\mathrm{Zn}-\mathrm{Mg}$-Al hydrotalcites as solid base catalysts. The effects on biodiesel production of the methanol/oil molar ratio, reaction temperature, and catalysts amount were studied. Catalysts with $\mathrm{Zn}-\mathrm{Mg}-\mathrm{Al}$ molar ratio 3:3:1 exhibited maximum catalytic activity for transesterification of neem oil with methanol. The highest triglyceride conversion rate of $92.5 \%$ was achieved after $4 \mathrm{~h}$ of reaction at $65^{\circ} \mathrm{C}$, with a $10: 1$ molar ratio of methanol to neem oil and $7.5 \mathrm{~g}$ catalysts. It could be concluded that the calcined nanohydrotalcite is an effective catalysts for the synthesis of biodiesel from neem oil.

\section{Conflict of Interests}

The authors declare that there is no conflict of interests regarding the publication of this paper.

\section{References}

[1] F. Ma and M. A. Hanna, "Biodiesel production: a review," Bioresource Technology, vol. 70, no. 1, pp. 1-15, 1999.

[2] H. E. Hoydonckx, D. E. De Vos, S. A. Chavan, and P. A. Jacobs, "Esterification and transesterification of renewable chemicals," Topics in Catalysis, vol. 27, no. 1-4, pp. 83-96, 2004.

[3] A. Pandey, Handbook of Plant-Based Biofuels, Taylor \& Francis, Boca Raton, Fla, USA, 2008.

[4] S. Glišić, I. Lukic, and D. Skala, "Biodiesel synthesis at high pressure and temperature: analysis of energy consumption on industrial scale," Bioresource Technology, vol. 100, no. 24, pp. 6347-6354, 2009.

[5] H. V. Lee, Y. H. Taufiq-Yap, M. Z. Hussein, and R. Yunus, "Transesterification of jatropha oil with methanol over Mg-Zn mixed metal oxide catalysts," Energy, vol. 49, no. 1, pp. 12-18, 2013.

[6] S. Wang, Y. Wang, Y. Dai, and J. Jehng, "Preparation and characterization of hydrotalcite-like compounds containing transition metal as a solid base catalyst for the transesterification," Applied Catalysis A: General, vol. 439-440, pp. 135-141, 2012.

[7] F. Rey, V. Fornes, and J. M. Rojo, "Influence of Ni content on physico-chemical characteristics of $\mathrm{Ni}, \mathrm{Mg}, \mathrm{Al}-$ Hydrotalcite like compounds," Journal of the Chemical Society. Faraday Transactions, vol. 88, pp. 2233-2238, 1992.

[8] F. Cavani, F. Trifirò, and A. Vaccari, "Hydrotalcite-type anionic clays: preparation, properties and applications," Catalysis Today, vol. 11, no. 2, pp. 173-301, 1991.

[9] R. Manivannan and A. Pandurangan, "Formation of ethyl benzene and styrene by side chain methylation of toluene over calcined LDHs," Applied Clay Science, vol. 44, no. 1-2, pp. 137143, 2009.

[10] R. Manivannan and A. Pandurangan, "Side chain ethylation of toluene with ethanol over hydrotalcite-like compounds," Kinetics and Catalysis, vol. 51, no. 1, pp. 56-62, 2010.

[11] R. Manivannan and C. Karthikeyan, "Synthesis of biodiesel from neem oil using $\mathrm{Mg}-\mathrm{Al}$ nano hydrotalcite," Advanced Materials Research, vol. 678, pp. 268-272, 2013.

[12] M. J. Climent, A. Corma, S. Iborra, K. Epping, and A. Velty, "Increasing the basicity and catalytic activity of hydrotalcites by different synthesis procedures," Journal of Catalysis, vol. 225, no. 2, pp. 316-326, 2004.

[13] K. Parida and J. Das, "Mg/Al hydrotalcites: preparation, characterisation and ketonisation of acetic acid," Journal of Molecular Catalysis A: Chemical, vol. 151, no. 1-2, pp. 185-192, 2000.

[14] D. Tichit, M. H. Lhouty, A. Guida et al., "Textural properties and catalytic activity of hydrotalcites," Journal of Catalysis, vol. 151, no. 1, pp. 50-59, 1995.

[15] J. I. di Cosimo, J. V. Díez, M. Xu, E. Iglesia, and C. R. Apesteguía, "Structure and surface and catalytic properties of MgAl basic oxides," Journal of Catalysis, vol. 178, pp. 499-510, 1998.

[16] V. R. L. Constantino and T. J. Pinnavaia, "Basic properties of $\mathrm{Mg}^{2+} 1-\mathrm{x} \mathrm{Al}^{3+}$ layered double hydroxide intercalated by carbonate, hydroxide, chloride and sulfate anions," Inorganic chemistry, vol. 34, no. 4, pp. 883-892, 1995.

[17] S. Miyata and A. Okada, "Synthesis of hydrotalcite-like compounds and their physico-chemical properties-the systems $\mathrm{Mg}^{2+}-\mathrm{Al}^{3+}-\mathrm{SO}_{4}^{2}$ - and $\mathrm{Mg}^{2+}-\mathrm{Al}^{3+}-\mathrm{CrO}_{4}^{2-}$," Clays and Clay Minerals, vol. 25, no. 1, pp. 14-18, 1977.

[18] L. S. Birks and H. Friedman, "Particle size determination from $\mathrm{x}$-ray line broadening," Journal of Applied Physics, vol. 17, no. 8, pp. 687-691, 1946. 
[19] V. Dávila, E. Lima, S. Bulbulian, and P. Bosch, "Mixed Mg(Al)O oxides synthesized by the combustion method and their recrystallization to hydrotalcites," Microporous and Mesoporous Materials, vol. 107, no. 3, pp. 240-246, 2008.

[20] R. V. Prikhod'ko, M. V. Sychev, I. M. Astrelin, K. Erdmann, A. Mangel', and R. A. Van Santen, "Synthesis and structural transformations of hydrotalcite-like materials $\mathrm{Mg}-\mathrm{Al}$ and $\mathrm{Zn}$ Al," Russian Journal of Applied Chemistry, vol. 74, no. 10, pp. 1621-1626, 2001.

[21] M. J. Hernandez-Moreno, M. A. Ulibarri, J. L. Rendon, and C. J. Serna, "IR characteristics of hydrotalcite-like compounds," Physics and Chemistry of Minerals, vol. 12, no. 1, pp. 34-38, 1985.

[22] S. Kannan and C. S. Swamy, "Synthesis and physicochemical characterization of cobalt aluminium hydrotalcite," Journal of Materials Science Letters, vol. 11, no. 23, pp. 1585-1587, 1992.

[23] F. M. Cabello, D. Tichit, B. Coq, A. Vaccari, and N. T. Dung, "Hydrogenation of acetonitrile on nickel-based catalysts prepared from hydrotalcite-like precursors," Journal of Catalysis, vol. 167, no. 1, pp. 142-152, 1997.

[24] E. Kanezaki, "Intercalation of naphthalene-2,6-disulfonate between layers of $\mathrm{Mg}$ and $\mathrm{Al}$ double hydroxide: preparation, powder X-ray diffraction, fourier transform infrared spectra and X-ray photoelectron spectra," Materials Research Bulletin, vol. 34, no. 9, pp. 1435-1440, 1999.

[25] A. Corma, S. B. A. Hamid, S. Iborra, and A. Velty, "Lewis and Brönsted basic active sites on solid catalysts and their role in the synthesis of monoglycerides," Journal of Catalysis, vol. 234, no. 2, pp. 340-347, 2005.

[26] V. B. Kazansky, V. Y. Borovkov, and E. G. Derouane, "Diffuse reflectance IR-spectroscopy evidence of the unusual properties of platinum in $\mathrm{Pt} / \mathrm{Mg}(\mathrm{Al}) \mathrm{O}$ catalysts for the selective aromatization of n-alkanes," Catalysis Letters, vol. 19, no. 4, pp. 327-331, 1993.

[27] Y. H. Taufiq-Yap, H. V. Lee, M. Z. Hussein, and R. Yunus, "Calcium-based mixed oxide catalysts for methanolysis of Jatropha curcas oil to biodiesel," Biomass and Bioenergy, vol. 35, no. 2, pp. 827-834, 2011.

[28] M. A. Olutoye and B. H. Hameed, " $\mathrm{KyMg}_{1-x} \mathrm{Zn}_{1+x} \mathrm{O}_{3}$ as a heterogeneous catalyst in the transesterification of palm oil to fatty acid methyl esters," Applied Catalysis A: General, vol. 371, no. 1-2, pp. 191-198, 2009.

[29] X. Deng, Z. Fang, Y. H. Liu, and C. L. Yu, "Production of biodiesel from Jatropha oil catalyzed by nanosized solid basic catalyst," Energy, vol. 36, no. 2, pp. 777-784, 2011. 

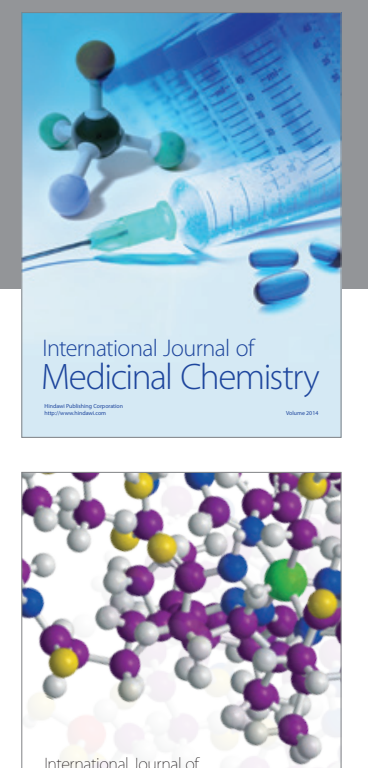

\section{Carbohydrate} Chemistry

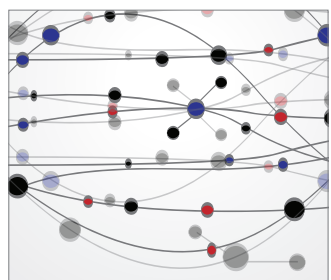

The Scientific World Journal
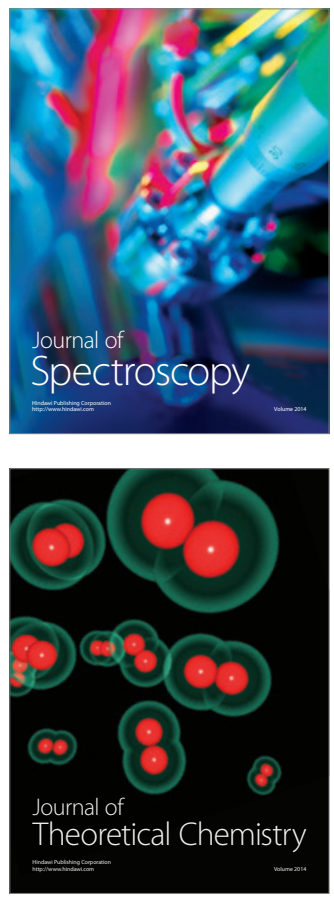
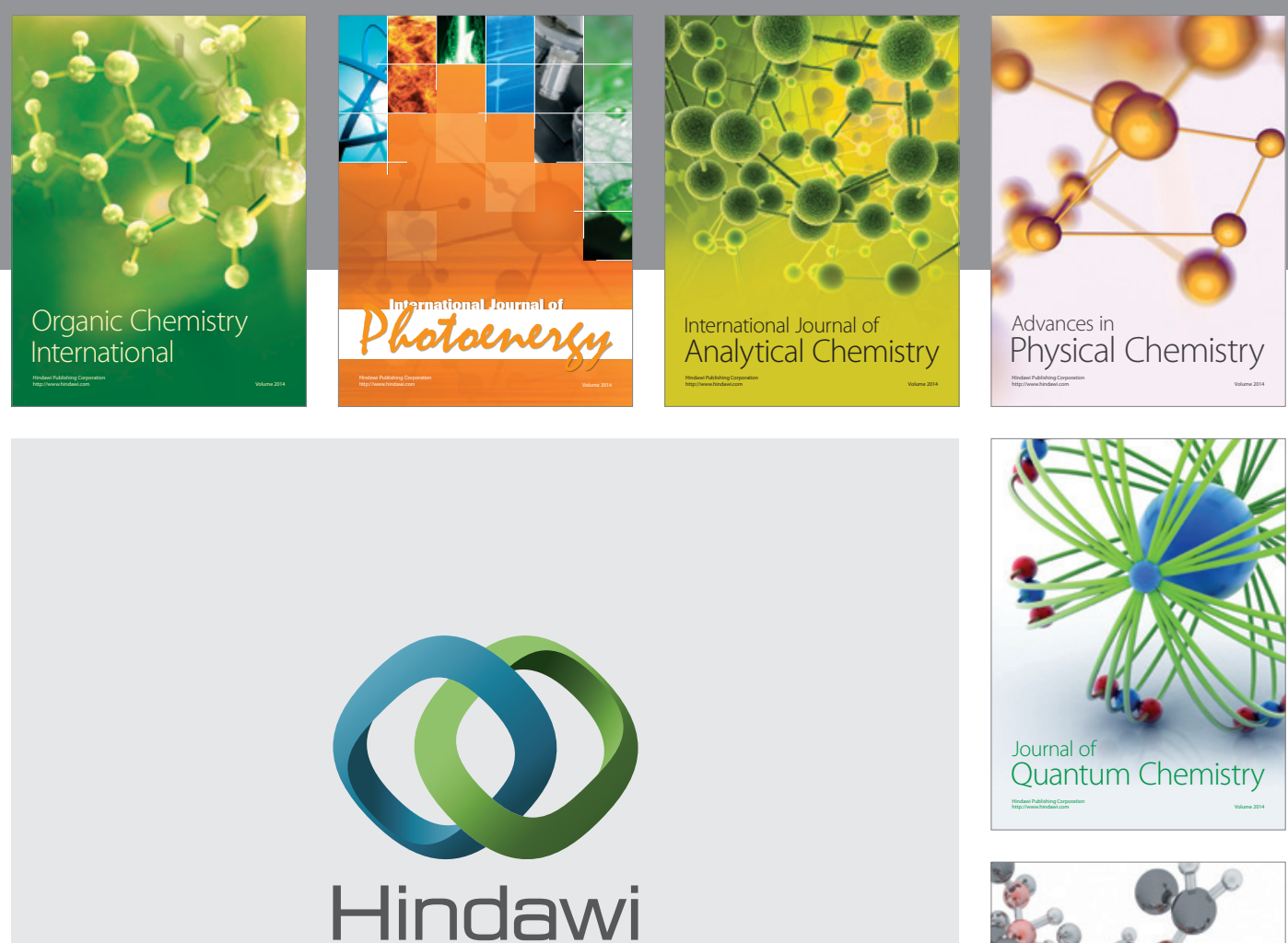

Submit your manuscripts at

http://www.hindawi.com

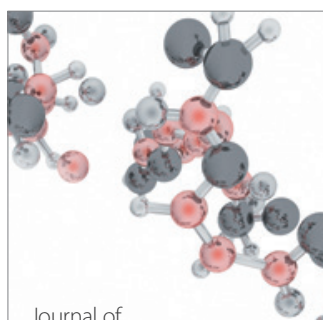

Analytical Methods

in Chemistry

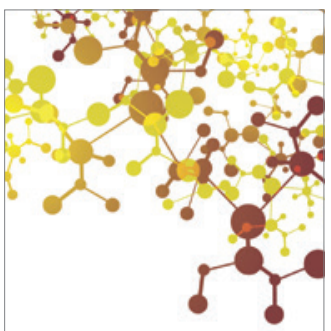

Journal of

Applied Chemistry

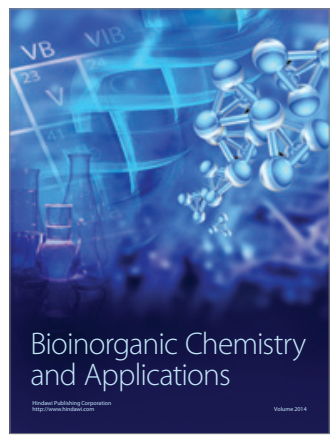

Inorganic Chemistry
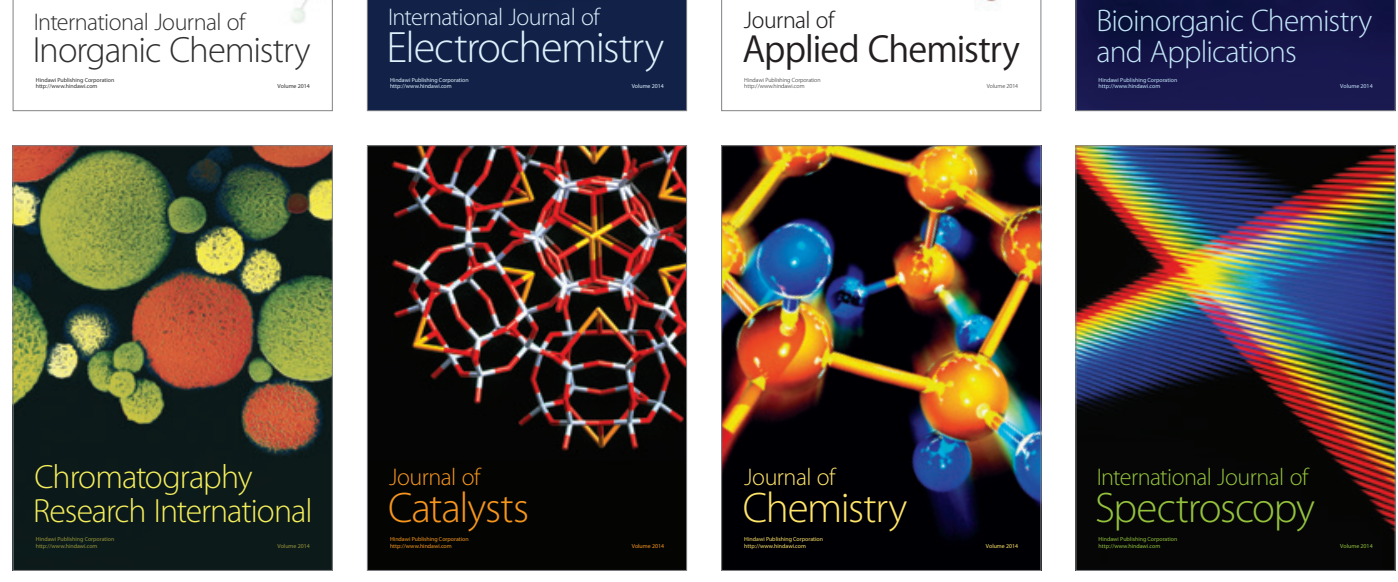